\title{
Kajian Kelayakan Pembentukan Sentra Peternakan Sapi di Sumatera Utara (Studi Kasus Kabupaten Batubara)
}

\section{Study of Feasibility on The Establishment of Cattle Farming Centers in North Sumatra (Case Study of Batubara District)}

\author{
Eddi Vanhuri'1), Hasnudi2), Yusniar Lubis ${ }^{3)}$
}

1) Program Studi Magister Agribisnis, Pascasarjana, Universitas Medan Area, Indonesia

2) Departemen Peternakan, Fakultas Pertanian, Universitas Sumatera Utara, Indonesia

3) Magister Agribisnis, Pascasarjana, Universitas Medan Area, Indonesia

\begin{abstract}
Abstrak
Penelitian ini bertujuan untuk menganalisis kelayakan usaha sentra peternakan sapi di Kabupaten Batubara dari aspek finansial dan aspek non finansial, serta menganalisis pola pengembangan sentra peternakan sapi di Kabupaten Batubara. Metode penelitian ini menggunakan pendekatan kuantitatif. Sampel ditentukan dengan metode simple random sampling sebanyak 50 orang. Pengumpulan data melalui kuesioner. Data dianalisis dengan menggunakan kelayakan finansial dan kelayakan non finansial. Hasil penelitian menunjukkan bahwa usaha peternakan sapi di Kabupaten Batubara dilihat dari kriteria investasi kegiatan usaha layak dikembangkan. Nilai R/C sebesar 1,61. Sentra peternakan sapi di Kabupaten Batubara berdasarkan aspek nonfinansial adalah layak dari segi aspek pasar, aspek sosial, ekonomi, dan budaya serta aspek lingkungan sekitar. Sedangkan dari aspek teknis, aspek manajemen dan hukum, masih perlu dibenahi. Pengembangan sentra peternakan sapi di Kabupaten Batubara dapat dilakukan dengan pola peternakan rakyat dengan sistem integrasi terhadap kawasan-kawasan disekitarnya dapat dilakukan dengan penataan dan kerjasama antara berbagai pihak-pihak yang terkait, khususnya perkebunan, yaitu: kawasan integrasi sawit-sapi; kawasan integrasi sapi-karet; dan kawasan integrasi sapi-tanaman pangan.

Kata kunci: kelayakan usaha, sentra peternakan, sapi.
\end{abstract}

\begin{abstract}
The aims of study to analyze the feasibility of cow farming center in Batubara Regency from financial aspect and non financial aspect, and to analyze the pattern of development of cow farming center in Batubara Regency. This research using a quantitative approach with survey on the type of research. The sample was determined by simple random sampling method, 50 people. The data collection through questionnaires. Data were analyzed using financial feasibility and non financial feasibility. The results showed that the cow farming center in the Batubara Regency from the investment criteria of business activities is feasible, the $R / C$ value is 1.61. The cow farming center in Batubara Regency based on nonfinancial aspects is feasible in terms of market, social, economic, and cultural aspects as well as environmental aspects. Meanwhile, from the technical aspects, management and legal aspects, still need to be addressed. The development of cow farming center in Batubara Regency can be done with the pattern of community livestock with the system of integration to the surrounding areas by arranging and cooperation between various related parties, especially the plantation, that is: the area integration of cow-palm; cow-rubber integration areas; and the integration of cow-food crops.
\end{abstract}

Keywords: business feasibility, cow farming center.

How to Cite: Vanhuri, E., Hasnudi \& Y. Lubis. (2019). Kajian kelayakan Pembentukan Sentra Peternakan Sapi di Sumatera Utara (Studi Kasus Kabupaten Batubara). Jurnal Ilmiah Magister Agribisnis, 1(1) 2019: 47-55,

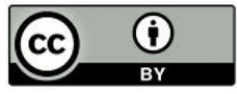


Vanhuri, E., Hasnudi \& Y. Lubis. Kajian kelayakan Pembentukan Sentra Peternakan Sapi di Sumatera Utara (Studi Kasus Kabupaten Batubara).

\section{PENDAHULUAN}

Pembangunan sub-sektor peternakan merupakan bagian dari pembangunan sektor pertanian, yang memiliki nilai strategis dalam memenuhi kebutuhan bahan pangan yang terus meningkat atas bertambahnya jumlah penduduk Indonesia, peningkatan rata-rata pendapatan penduduk Indonesia, taraf hidup petani dan nelayan. Keberhasilan pembangunan tersebut ternyata berdampak pada perubahan konsumsi masyarakat yang semula lebih banyak mengkonsumsi karbohidrat ke arah konsumsi protein hewani seperti daging, telur dan susu. Namun saat ini untuk memenuhi kebutuhan daging dalam negeri, tidak diimbangi oleh produksi yang optimal.

Ternak sapi, merupakan salah satu sumber daya penghasil bahan makanan berupa daging yang memiliki nilai ekonomis yang tinggi, dan penting artinya di dalam kehidupan masyarakat (Siregar, 1996). Kebutuhan daging sapi di Indonesia saat ini dipasok dari tiga pemasok yaitu : peternak rakyat (ternak lokal), industri peternakan rakyat (hasil penggemukan sapi) dan impor daging. Selanjutnya untuk tetap menjaga keseimbangan antara penawaran dan permintaan ternak sapi, usaha peternakan rakyat tetap menjadi tumpuan utama, namun tetap menjaga kelestarian sumberdaya ternak.

Salah satu target program pembangunan peternakan di Sumatera Utara adalah optimalisasi pemanfaatan teknologi peternakan yang dicapai melalui program peningkatan pemanfaatan teknologi, khususnya pemanfaatan teknologi Inseminasi Buatan (IB). Indikator kinerja utama dari program ini adalah pencapaian jumlah akseptor IB dari 56.000 ekor (2014) menjadi 78.670 ekor pada tahun 2018. Indikator kinerja utama lainnya adalah jumlah kelahiran IB yang mencapai 40.000 ekor (2014) dan meningkat menjadi 56.642 ekor pada tahun 2018 (Dinas Peternakan dan Kesehatan Hewan Prov. Sumatera Utara, 2017).

Pelaksanaan program tersebut meliputi seluruh wilayah kabupaten di Sumatera Utara, salah satu diantaranya adalah Kabupaten Batubara. Wilayah Kabupaten Batubara dengan potensi areal pertanian dan perkebunan yang luas, mendukung ketersediaan pakan ternak dari hasil pertanian terutama pemanfaatan limbah pertanian dan perkebunan, serta keadaan yang mendukung dalam pengembangan ternak unggas serta integrasi usaha ternak sapi, kambing dan domba dengan perkebunan kelapa sawit. Wilayah Kabupaten Batubara telah menjadi sentra pengembangan ternak sapi, dan menjadi pemasok terbesar ternak sapi di Sumatera Utara, ke wilayah kabupaten/kota lain bahkan hingga ke luar provinsi.

Hal ini sejalan dengan visi dan misi Dinas Peternakan Kabupaten Batu Bara. Salah satu sasaran dari program pembangunan peternakan tahun 2013-2018 di Kabupaten Batubara adalah meningkatnya produksi dan produktivitas peternakan. Memperhatikan potensi wilayah dan sumberdaya manusia yang tersedia, maka Kabupaten Batubara dapat dijadikan menjadi sentra peternakan sapi di Provinsi Sumatera Utara. Sapi mempunyai potensi ekonomi yang tinggi baik sebagi ternak potong maupun ternak bibit. 
Pembentukan atau pengembangan sentra peternakan sapi merupakan salah satu investasi yang akan memberikan banyak keuntungan bagi wilayah Kabupaten Batubara.

Investasi pembentukan sentra peternakan sapi ini memerlukan biaya yang cukup besar, sedangkan modal merupakan sumberdaya terbatas sehingga perlu dilakukan analisis kelayakan pengembangan usaha. Analisis kelayakan usaha ini dilihat dari beberapa aspek yaitu aspek pasar, aspek teknis, aspek manajemen, aspek sosial, ekonomi dan lingkungan, aspek hukum serta aspek finansial.

\section{METODE PENELITIAN}

Penelitian dilakukan di Kabupaten Batubara. Pemilihan lokasi penelitian dilakukan secara sengaja (purposive), berdasarkan keterjangkauan pengumpulan data. Jenis data yang digunakan pada penelitian ini adalah data primer dan data sekunder. Data primer diperoleh melalui pengamatan langsung di usaha peternakan sapi dan lokasi yang terkait dengan penelitian ini serta wawancara dengan peternak sapi. Data primer sebagian besar diperoleh dengan menggunakan instrument berupa daftar pertanyaan. Untuk keperluan data primer, dilakukan pengumpulan data dari kelompok peternak, sebesar $50 \%$, yaitu sebanyak 50 kelompok peternak. Data sekunder diperoleh dari hasil studi pustaka dan literatur berbagai buku, skripsi terdahulu dan data internal dari beberapa instansi terkait, seperti Dinas Peternakan, Badan Pusat Statistik (BPS), serta referensi dari media massa, baik cetak maupun elektronik.

Analisis yang digunakan pada penelitian ini adalah analisis kualitatif dan kuantitatif. Analisis kualitatif yang dilakukan merupakan analisis deskriptif yang berupa gambaran sistem usaha dan aspek nonfinansial yang terdiri dari aspek pasar, teknis, manajemen dan hukum, aspek sosial, ekonomi, budaya, serta aspek lingkungan dari usaha peternakan sapi di Kabupaten Batibara. Analisis data secara kuantitatif digunakan untuk mengetahui tingkat kelayakan finansial yang meliputi biaya-biaya yang dikeluarkan mencakup biaya investasi dan biaya operasional serta penerimaan dari hasil penggemukan sapi berdasarkan kriteria $\mathrm{R} / \mathrm{C}$ dan laba rugi. Kriteria investasi berdasarkan $\mathrm{R} / \mathrm{C}$ ratio adalah: $R / \mathrm{C}=1$, maka usaha impas; $R / C>1$, maka usaha layak dikembangkan; $R / C<1$, maka usaha tidak layak dikembangkan.

\section{HASIL DAN PEMBAHASAN}

Kondisi Peternakan Sapi

Kondisi peternakan sapi di Kabupaten Batubara dapat dilihat dari jumlah populasi ternak dan perkembangan populasi ternak setiap tahun. Jumlah ternak sapi di Kabupaten Batubara mengalami peningkatan setiap tahun, sebagaimana disajikan pada tabel 1. Data perkembangan populasi ternak sapi tersebut menunjukkan bahwa setiap tahun terjadi peningkatan jumlah ternak sapi di Kabupaten Batubara. Usaha ternak sapi di Kabupaten Batubara dilakukan oleh rumah tangga peternak, yang pada umumnya juga mengusahakan lahan perkebunan. 
Vanhuri, E., Hasnudi \& Y. Lubis. Kajian kelayakan Pembentukan Sentra Peternakan Sapi di Sumatera Utara (Studi Kasus Kabupaten Batubara).

Tabel 1. Perkembangan Populasi Sapi di Kabupaten Batubara

\begin{tabular}{llll}
\hline \multirow{2}{*}{ Tahun } & Sapi (ekor) & \multicolumn{2}{l}{ Perkembangan } \\
\cline { 3 - 4 } & & Jumlah & $\%$ \\
\hline 2008 & 23.038 & - & - \\
2009 & 23.755 & 717 & 3,11 \\
2010 & 24.432 & 677 & 2,85 \\
2011 & 25.813 & 1.381 & 5,65 \\
2012 & 27.598 & 1.785 & 6,92 \\
2013 & 27.785 & 187 & 0,68 \\
2014 & 28.366 & 581 & 2,09 \\
2015 & 30.891 & 2.525 & 8,90 \\
2016 & 38.500 & 7.609 & 24,63 \\
\hline
\end{tabular}

Sumber: Dinas Peternakan dan Perkebunan Kabupaten Batubara, 2017

Jumlah ternak sapi yang dipelihara oleh setiap rumah tangga peternak sangat bervariasi, sebagian besar dipengaruhi oleh ketersediaan modal. Jumlah rumah tangga peternak sapi di Kabupaten Batubara adalah sebagai berikut.

Tabel 2. Jumlah Rumah Tangga Peternak Sapi di Kabupaten Batubara, 2016

\begin{tabular}{clccc}
\hline No. & Kecamatan & Jumlah Ternak (ekor) & Jumlah RT Peternak & $\begin{array}{l}\text { Ternak } \\
\text { (ekor) }\end{array}$ \\
\hline 1. & Sei Balai & 4.679 & 1.204 & 4 \\
2. & Tanjung Tiram & 1.057 & 253 & 4 \\
3. & Talawi & 4.126 & 740 & 6 \\
4. & Lima Puluh & 19.150 & 3.817 & 5 \\
5. & Air Putih & 509 & 106 & 5 \\
6. & Sei Suka & 8.520 & 1.600 & 5 \\
7. & Medang Deras & 459 & 101 & 5 \\
\hline
\end{tabular}

Sumber: Dinas Peternakan dan Perkebunan Kabupaten Batubara, 2017

Analisis Kelayakan Usaha Ternak Sapi

Analisis Kelayakan Finanasial

Pemikiran tentang pengembangan sentra peternakan sapi di Kabupaten Batubara berasal dari perkembangan jumlah sapi dan rumah tangga peternak setiap tahun. Oleh karena itu, perlu dilakukan analisis terhadap usaha ternak sapi yang seluruhnya dilakukan oleh masyarakat (peternakan rakyat). Sehubungan dengan hal tersebut dilakukan analisis usaha peternakan sapi yang dikelola masyarakat sebagai cikal bakal pengembangan sentra peternakan berbasis peternakan rakyat..

Berdasarkan data responden, diketahui bahwa setiap responden sebagai peternak memelihara ternak sapi sebanyak 2 - 132 ekor, atau rata-rata 20 ekor. Hal ini menunjukkan bahwa sebagian usaha ternak sapi sudah tergolong intensi walaupun 
dilakukan dalam skala usaha keluarga. Sebagian ternak merupakan penggemukan dari tahun sebelumnya, atau anak dari induk yang dipelihara, sebagian diperoleh dengan membeli bibit ternak dari para agen yang ada di Kabupaten Batubara. Jumlah bibit ternak yang dibeli responden pada saat penelitian dilakukan adalah antara $1-4$ ekor, atau rata-rata 8 ekor per peternak. Oleh karena itu, komponen biaya bibit yang dihitung dalam analisis usaha peternakan ini adalah bibit yang dibeli peternak. Umur analisis dilakukan hanya untuk dua tahun karena peternak sudah menjual ternak pada umur dua tahun. Rata-rata biaya usaha peternakan sapi dirangkum dalam tabel sebagai berikut.

Tabel 3. Rata-rata Biaya Usaha Peternakan Sapi (Rp Juta/Tahun)

\begin{tabular}{|c|c|c|c|c|}
\hline No & Uraian & Maks & Min & Rata-rata \\
\hline 1. & Biaya bibit & 288,00 & 0,00 & 59,05 \\
\hline 2. & Biaya tenaga kerja & 96,00 & 0,00 & 24,50 \\
\hline 3. & Biaya pakan & 79,20 & 2,57 & 15,85 \\
\hline 4. & Penyusutan kandang & 32,50 & 0,00 & 3,10 \\
\hline 5. & Biaya lain-lain & 2,98 & 0,00 & 0,55 \\
\hline & Total biaya & 458,33 & 7,66 & 103,05 \\
\hline & Jumlah ternak & 132 & 3 & 22 \\
\hline & Biaya /ekor ternak & 9,72 & 1,91 & 5,55 \\
\hline
\end{tabular}

Sumber: Data Primer Diolah, 2017

\section{Penerimaan Usaha (Penjualan)}

Sumber penerimaan utama dari peternakan sapi adalah dari hasil penjualan sapi tersebut hal ini dapat dilihat pada tabel 4. Sapi dapat dijual setelah berumur 6 bulan hingga berumur 2 tahun. Harga penjualan berbeda untuk sapi dengan umur $6-12$ bulan dan umur 2 tahun. Sapi dijual kepada agen yang pada umumnya adalah agen lokal. Selain sapi, peternak juga sebagian ada yang menjual kotoran sapi kepada para petani di sekitar lokasi peternakan, namun dalam analisis ini, hasil penjualan kotoran sapi tidak dimasukkan sebagai komponen penjualan.

Tabel 4. Rata-rata Penjualan Sapi

\begin{tabular}{clrrr}
\hline No. & Uraian & Maks & Min & \multicolumn{2}{c}{ Rata-rata } \\
\hline 1. & Jumlah sapi dijual (ekor) & 55,00 & 0,00 & 5,52 \\
2. & Harga jual per ekor (Rp juta) & 10,83 & 6,50 & 8,93 \\
3. & Total penjualan (Rp juta) & 525,20 & 0,00 & 49,60 \\
\hline
\end{tabular}

Sumber: Data Primer Diolah, 2017.

Pendapatan Usaha (Laba Rugi)

Tabel 5. Pendapatan Usaha Sapi

\begin{tabular}{clrrr}
\hline No. & Uraian & Maks & Min & Rata-rata \\
\hline 1. & Harga jual per ekor (Rp juta) & 10,83 & 6,50 & 8,93 \\
2. & Biaya /ekor ternak (Rp juta) & 9,72 & 1,91 & 5,55 \\
3. & Profit per ekor (Rp juta) & 8,09 & 0,03 & 3,31 \\
\hline
\end{tabular}

Sumber: Data Primer Diolah, 2017.

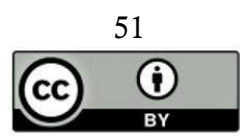


Berdasarkan biaya dan penjualan per ekor tersebut juga dapat dihitung nilai R/C ratio, sebagai berikut:

$\mathrm{R} / \mathrm{C}=$ Total Penerimaan / Total Biaya

Rata-rata penerimaan per ekor sapi adalah sebesar Rp. 8,93 juta

Rata-rata biaya per ekor sapi adalah sebesar Rp. 5,55 juta

Sehingga $\mathrm{R} / \mathrm{C}=1,61$

Dengan demikian $\mathrm{R} / \mathrm{C}>1$ sehingga usaha layak dikembangkan.

\section{Analisis Kelayakan Non Finansial}

Aspek Pasar

Pasar sudah mendukung dalam pengembangan usaha sapi di Kabupaten Batubara, yang juga sekaligus menunjukkan bahwa sistem pasar sudah berlangsung dengan baik, sehingga dari aspek pasar bahwa potensi usaha peternakan sapi yang dilakukan masyarakat sudah layan dikembangkan menjadi sentra peternakan sapi. Salah satu aspek pasar yang cukup berpengaruh terhadap pengembangan usaha adalah permintaan yang terus meningkat.

Aspek Teknis

Aspek teknis yang berkaitan dengan usaha pengembangan sapi di Kabupaten Batubara berkaitan dengan penyediaan bibit, pakan, obat-obatan dan dokter hewan. Berdasarkan informasi dari responden, bahwa hingga saat ini, para peternak masih kesusahan untuk memperoleh bibit sapi unggul, dan kalau ada harganya cukup mahal. Dari segi penyediaan pakan, di Kabupaten Batubara tersedia lahan perkebunan yang dapat menjadi sumber pakan hijauan untuk ternak sapi. Dari aspek kesehatan ternak, yaitu ketersediaan obat-obatan dan dokter hewan masih sangat terbatas.

Aspek Manajemen

Berdasarkan hasil penelitian bahwa usaha peternakan sapi di Kabupaten Batubara dilakukan dalam skala usaha kecil (peternakan rakyat), namun demikian dari teknis pengelolaan usaha sudah dapat dilakukan dengan cukup baik.

Aspek Hukum

Berdasarkan data yang diperoleh dari responden, belum ada usaha peternakan responden yang telah berbadan hukum. Para peternak pada umumnya sudah tergabung dalam satu kelompok peternak, tetapi masih ada juga yang belum menjadi anggota kelompok.

Aspek Ekonomi dan Sosial

Dari segi aspek ekonomi dan sosial, bahwa pengembangan usaha peternakan sapi layak dikembangkan di Kabupaten Batubara. Selain memberikan keuntungan secara langsung kepada peternak, usaha peternakan sapi juga memberikan kesempatan kerja kepada masyarakat, dalam hal sebagai tenaga kerja pemeliharaan kandang dan ternak. Aspek Lingkungan 
Usaha peternakan sapi merupakan salah satu kegiatan yang ramah lingkungan, karena adanya hubungan timbal balik yang cukup baik antara lingkungan dan sapi itu sendiri. Sapi membutuhkan hijauan sebagai pakan, sehingga dalam suatu lingkungan peternakan perlu dijaga suatu areal tertentu sebagai sumber pakan. Kotoran sapi juga sangat bermanfaat bagi lingkungan, yang dapat digunakan sebagai pupuk organik. Dengan demikian peternakan sapi juga mendukung pengembangan pertanian organik, yang sejatinya merupakan pertanian ramah lingkungan.

Hasil penelitian menunjukkan bahwa usaha peternakan sapi yang dilakukan masyarakat di Kabupaten Batubara layak secara ekonomis, sehingga layak dikembangkan. Pola pemeliharaan ternak sapi yang dilakukan masyarakat di Kabupaten Batubara masih berskala kecil. Oleh karena itu dalam pengembangan sentra peternakan sapi di Kabupaten Batubara sebaiknya dilakukan dengan pola atau sistem peternakan rakyat. Artinya Pemerintah Kabupaten membina usaha peternakan rakyat menjadi lebih efisien dan profesional sehingga benar-benar menjadi usaha dalam skala yang menguntungkan bagi peternak dan juga bagi pengembangan daerah.

Sebagian besar wilayah Kabupaten Batubara merupakan lahan perkebunan, baik kelapa sawit maupun karet serta tanaman pangan. Oleh karena itu dalam pengembangan sentra peternakan sapi, perlu dilakukan sistem integrasi antar komoditas, khususnya antara ternak sapi dengan lahan perkebunan dan persawahan. Dari luas lahan tanaman perkebunan dan juga luas lahan tanaman pangan yang ada di Kabupaten Batubara menghasilkan daya dukung untuk penambahan populasi ternak sapi sesuai tabel dibawah ini.

Tabel 6. Daya Dukung Tanaman Perkebunan

\begin{tabular}{llrllr}
\hline No. & Komoditi & $\begin{array}{l}\text { Luas } \\
\text { Tanaman } \\
\text { (Ha) }\end{array}$ & $\begin{array}{l}\text { Daya Dukung } \\
\text { (ST/Ha) }\end{array}$ & $\begin{array}{l}\text { Jenis Pakan } \\
\text { (Limbah) }\end{array}$ & $\begin{array}{l}\text { Jumlah } \\
\text { Ternak (ST) } \\
* *\end{array}$ \\
\hline 1. & Perkebunan Swasta/ & & & & \\
& BUMN-Sawit-Karet & 20.412 & 7 & Pelepah, Lumpur, BIS & 142.884 \\
& & 4.001 & 5 & Biji Karet & 20.005 \\
& & & & \\
2. & & & & 48.172 \\
& Perkebunan Rakyat & 12.043 & 4 & Pelepah, Lumpur, BIS & 1.545 \\
& -Sawit & 515 & 3 & Biji Karet & 4.088 \\
& -Karet & 2.044 & 2 & Kulit/Kolven & 216.694 \\
& -Kakao & 39.014 & & &
\end{tabular}

Sumber: Data Primer Diolah, 2017

*) Hasil Perhitungan Model Dept. Peternakan Fak. Pertanian USU

**) Hasil Perhitungan dari Data Luas Kebun 
Tabel 7. Daya Dukung Tanaman Pangan

\begin{tabular}{llrllr}
\hline No. & Komoditi & $\begin{array}{l}\text { Luas Panen } \\
\text { (Ha) }\end{array}$ & $\begin{array}{l}\text { Daya } \\
(\mathrm{ST} / \mathrm{Ha})^{*}\end{array}$ & $\begin{array}{l}\text { Dukung } \\
\text { (Limbah) }\end{array}$ & $\begin{array}{l}\text { Jumlah } \\
\text { (ST)** }\end{array}$ \\
\hline 1. & Padi Sawah & 35.760 & 1,136 & Jerami & 40.623 \\
2. & Jagung & 350 & 4,986 & Jerami & 1.741 \\
3. & Ubi Kayu & 731 & 0,767 & Daun & 1.745 \\
4 & Ubi Jalar & 26 & 1,874 & Daun & 561 \\
5. & Kacang Kedelai & 80 & 1,269 & Jerami & 49 \\
6. & Kacang Tanah & 15 & 1,740 & Jerami & 101 \\
7. & Kacang Hijau & 7 & 1,269 & Jerami & 269 \\
\hline & Jumlah & 36.969 & & & 43.114 \\
\hline
\end{tabular}

Sumber: Data Primer Diolah, 2017

*) Hasil Perhitungan Model Direktorat Bina Usaha Petani Ternak dan Pengolahan Hasil Peternakan, Dikjen Peternakan, 1985

**) Hasil Perhitungan dari Data Luas Tanaman Pangan

Dari tabel 6 dan tabel 7 maka daya tampung sapi berdasarkan tanaman perkebunan dan tanaman pangan untuk Kabupaten Batubara dapat menampung penambahan populasi ternak sebanyak 216.694 ST untuk tanaman perkebunan dan sebanyak 43.114 ST untuk tanaman pangan. Jadi secara keseluruhan dapat menampung 259.808 ST di Kabupaten Batubara.

Berdasarkan kondisi tersebut, maka pengembangan sentra peternakan sapi di Kabupaten Batu Bara dapat dilakukan melalui pola integrasi, yaitu:

Kawasan integrasi sapi - sawit

Kawasan integrasi sapi - karet

Kawasan integrasi sapi - tanaman pangan.

\section{SIMPULAN}

Usaha peternakan sapi di Kabupaten Batubara dilihat dari kriteria investasi dan kegiatan usaha layak dikembangkan. Sentra peternakan sapi di Kabupaten Batubara berdasarkan aspek nonfinansial adalah layak dari segi aspek pasar, aspek sosial, ekonomi, dan budaya serta aspek lingkungan sekitar. Sedangkan dari aspek teknis, aspek manajemen dan hukum, masih perlu dibenahi. Pengembangan sentra peternakan sapi di Kabupaten Batubara dapat dilakukan dengan pola peternakan rakyat dengan sistem integrasi terhadap kawasan-kawasan disekitarnya dapat dilakukan dengan penataan dan kerjasama antara berbagai pihak-pihak yang terkait, khususnya perkebunan. 
Dalam upaya pengembangan sentra peternakan sapi di Kabupaten Batubara perlu peran Pemerintah Daerah dalam hal aspek teknis, hukum dan manajemen, karena pengusahaan peternakan di Kabupaten Batubara masih pola peternakan rakyat. Dalam hal aspek pasar, sosial ekonomi, dan aspek lingkungan juga masih diperlukan campur tangan pemerintah daerah, agar kepentingan peternak dapat terlindungi, khususnya dalam menjalin kerjasama dengan perusahaan perkebunan sebagai area penggembalaan atau sumber pakan. Pengembangan kawasan - kawasan intergrasi dapat dilakukan melalui kerjasama dengan pihak perkebunan yang difasilitasi atau di dukung oleh Pemerintah Kabupaten.

\section{DAFTAR PUSTAKA}

Dinas Peternakan Kabupaten Batubara, Rencana Strategis Dinas Peternakan Kabupaten Batubara Tahun 2013 - 2018.

Direktorat Jendral Peternakan dan Kesehatan Hewan, 2015. Pedoman Sentra Peternakan Rakyat (SPR). Jakarta: Kementerian Pertanian Republik Indonesia.

Faisal, Muhammad, 2010.Analisis Tataniaga Sapi Potong PT. Kariyana Gita Utama, Cicurug, Sukabumi. Bogor: Fakultas Ekonomi dan Manajemen, Institut Pertanian Bogor.

Gittinger JP. 1986. Analisa Ekonomi Proyek-Proyek Pertanian. Jakarta: UI Press.

Ibrahim Y. 1998. Studi Kelayakan Bisnis. Jakarta: Rineka Cipta.

Johan S. 2011. Studi Kelayakan Pengembangan Bisnis. Yogyakarta: Graha Ilmu.

Kasmir dan Jakfar. 2009. Studi Kelayakan Bisnis. Jakarta: Kencana Prenada Media Group.

Muzayin. 2008. Analisis kelayakan usaha instalasi biogas dalam mengelola limbah ternak sapi potong pada PT. Widodo Makmur Perkasa, Cianjur, Bogor, Jawa Barat. Bogor: Fakultas Ekonomi dan Manajemen, Institut Pertanian Bogor.

Novra, Ardi dan Adriani, 2015. Masterplan Pembangunan Kawasan Peternakan Sapi Potong Provinsi Jambi. Kerjasama Dinas Peternakan dan Kesehatan Hewan Provinsi Jambi dengan LP3M Universitas Jambi.

Nurmalina R, Sarianti T, Karyadi A. 2009. Studi Kelayakan Bisnis. Bogor: Departemen Agribisnis Fakultas Ekonomi dan Manajemen Institut Pertanian Bogor.

Pusat Penelitian dan Pengembangan Peternakan. 2007. Perkandangan Sapi Potong. Jakarta: BPPT, Departemen Pertanian

Rahmat dan Bagus. 2012. 3 Jurus Sukses Menggemukan Sapi Potong. Jakarta: Penebar Swadaya.

Rangkuti, Freddy, 2009. Analisis SWOT Teknik Membedah Kasus Bisnis. Jakarta: PT. Gramedia Pustaka Utama.

Rivai, Arif. 2009. Analisis Kelayakan Usaha Penggemukan Sapi Potong (Fattening) Pada PT Zagrotech Dafa Internasional (ZDI), Ciampea, Bogor, Jawa Barat. Bogor: Fakultas Ekonomi dan Manajemen, Institut Pertanian Bogor.

Robinson, Pearce, 1997. Manajemen Stratejik Formulasi, Implementasi dan Pengendalian, Jilid 1. Jakarta: Binarupa Aksara.

Sagala, Windayani. 2011. Analisis Biaya Pakan dan Performa Sapi Potong Lokal Pada Ransum Hijauan Tinggi yang Disuplementasi Ekstrak Lerak (Sapindus rarak). Bogor: Fakultas Peternakan, Institut Pertanian Bogor.

Sugeng. B.Y. 2006. Sapi Potong. Jakarta: Penebar Swadaya

Suliyanto. 2010. Studi Kelayakan Bisnis Pendekatan Praktis. Yogyakarta: Andi.

Soeprapto, H. dan Z. Abidin. 2006. Cara Tepat Penggemukan Sapi Potong. Jakarta: PT Agromedia Pustaka.

Umar H. 2007. Studi Kelayakan Bisnis Teknik Menganalisis Kelayakan Rencana Bisnis Secara Komprehensif. Jakarta: Gramedia Pustaka Utama.

Yulianto dan Cahyo. 2011. Penggemukan Sapi Potong Hari Per Hari 3 Bulan Panen. Jakarta: Penebar Swadaya.

Yulianto dan Cahyo. 2010. Pembesaran Sapi Potong Secara Intensif. Jakarta: Penebar Swadaya.

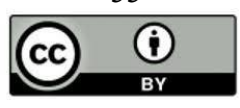

